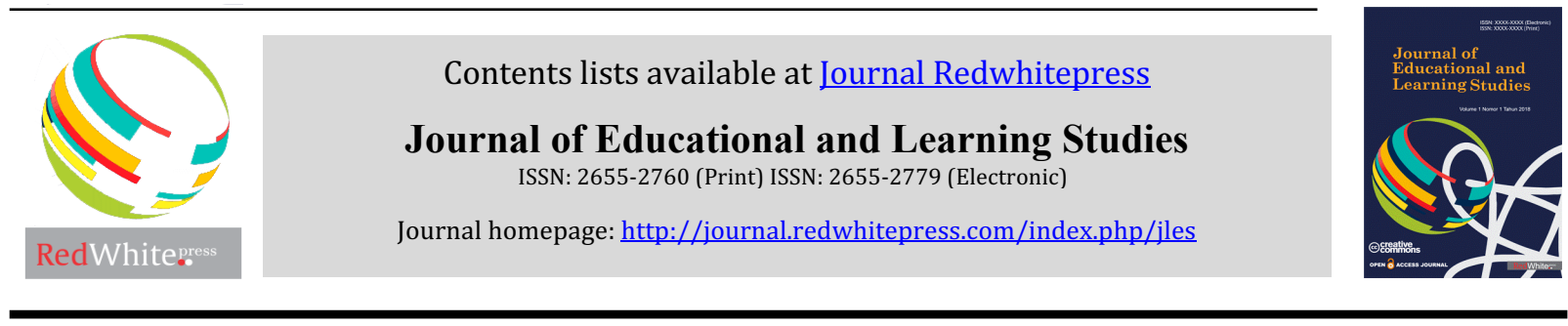

\title{
The Differences of Honest Characters of Students Before and After Learning with A Model of Learning of Intelligent Character
}

\author{
Famahato Lase ${ }^{1}$, Herman Nirwana ${ }^{1}$, Neviyarni ${ }^{1}$, Marjohan ${ }^{1}$ \\ ${ }^{1}$ Universitas Negeri Padang
}

\begin{tabular}{l}
\hline Article Info \\
\hline Article history: \\
Received Dec $15^{\text {th }}, 2020$ \\
Revised Jan $20^{\text {th }}, 2020$ \\
Accepted Jan $26^{\text {th }}, 2020$ \\
\hline
\end{tabular}

\section{Keyword:}

honest character learning model

\begin{abstract}
The purpose of this study was to to reveal the differences in honest character of students before and after being taught with a model of learning of inteligent character, using an experimental approach to the one group pretest posttest design method. Subjects, samples, and research data sources are 45 students of Gunungsitoli IKIP. The data collection instrument is a closed questionnaire that is based on seven principles of honest character, namely: speaking as is, acting on the basis of truth, defending the truth, being responsible, fulfilling obligations and accepting rights, being graceful, and keeping promises. The results showed that the intelligent character learning model can improve the honest character of students from not good to very good or from dishonest to very honest. It is recommended that every educator use this intelligent character learning model for all learning activities.
\end{abstract}

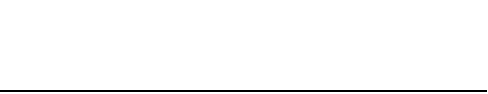

\section{Corresponding Author:}

Famahato Lase

Universitas Negeri Padang

Email: famahatolase@ikipgunungsitoli.ac.id
(C) 2020 The Authors. Published by Redwhitepress.

This is an open access article under the CC BY-NC-SA license (https://creativecommons.org/licenses/by-nc-sa/4.0/

\section{Introduction}

What are the consequences if students are only educated with reason without being accompanied by intelligent character education? What if they were only schooled and not educated in the values of intelligent characters? It is the same as building a threat in society (Theodore Rosevelt, 2013). The current moral crisis happens everywhere such as: violence, terrorism, murder, adultery, theft, LGBT (free sex, lesbian, gay, bisexual, transgender), corruption, drugs, lies, fraud, fraud, bank burglary, and others (Maslamah, 2016). The perpetrators of this crime (Sulistyowati, 2012) are not people who have never been to school, but instead they have all been in school, mastered science and technology, smart, clever and intelligent (Kemenko Kesra, 2010) but not characterized (Kirom, 2011). Why is it like that? Because they are actually only schooled and have not been educated in the values of intelligent characters (Chiara, 2016).

Humans are the most noble creatures of God, with a high degree, perfect among all creation and as a caliph on earth (Prayitno, 2015), created according to the character, the Creator. They are intelligent individuals who can be educated (Elizabeth, 2015) to be honest, responsible, have the highest duty of worship and serve God, are unique, have potential that is equipped with reason, feelings and will, noble character and become a caliph Ardh fil (Neviyarni, 2009). To educate individuals to be human with honest intelligent character, a smart character learning model is needed. 
Character is a mental, moral or moral nature that characterizes a person, group of people, or something that qualifies a person, becomes an identity, character, a permanent trait, which overcomes the ever-changing contingent experience (Sutarjo, 2013). Characters can also be explained as temperament or personality, traits or characteristics, style or characteristic of a person derived from forms received from the environment. Character as a description of behavior that accentuates the value of right and wrong, both explicitly and implicitly, is a manifestation of life that is realized through actions that are rightly related to oneself and others (Sigit 2013). The character of life is divided into two sides, namely righteous behavior in relation to oneself and a life full of virtues whose content is oriented to others, such as justice, honesty, gratitude and love, but also includes selforiented virtues such as humility, fortitude, self control, and try your best and do not give up on laziness (Lickona, 2012). Conceptually, character is defined as typical good values (knowing the value of goodness, willingness to do good, having a good life, and having a good impact on the environment) that is imprinted on oneself and manifested in behavior. While the character coherently emanates from the results of thought, heart, sports, as well as the feeling and intention of a person or group of people This character refers to a series of attitudes, behaviors, motivations, skills, are rules that serve as good and bad measures of attitude, speech, and action (Mujtahid, 2016). Good character is a concept that contains good knowledge, embraces good and does well. Characterized as personality, behavior, character, and character. Individual character will develop well if it gets the right reinforcement, namely in the form of education (Maunah, 2015). Character of good people as individuals who understand the good, love the good and do good (Aynur, 2011). Character develops from the mind; thoughts become words, words become deeds, deeds become habits, habits become characters, and characters become destiny (Lickona, 2012).

Honest can be interpreted as being upright, not cheating, sincere, and sincere, saying or giving information that is in accordance with reality and truth, not lying, trustworthy words and not betraying (Emosda, 2011). Opponents of honest words is a lie, mungkir, hypocritical which means to say or give information that is not in accordance with the truth (KBBI $\mathrm{v} 1,1,2010)$. Honesty can be explained as behavior that reflects the compatibility between heart, words and deeds. What is intended by the heart, spoken by word of mouth and described in action Honesty is very closely related to a conscience that always invites humans to goodness. Honesty refers to aspects of character, morals and connotes positive and virtuous attributes such as integrity, honesty, and directness, including directness in behavior, and go hand in hand with no lies, fraud, infidelity, and the like that honesty means trustworthy, loyal, fair, and sincere, which is valued by many ethnic cultures and religions (Rogers, 1964).

Honesty is an element of spiritual strength, noble character, personality that is reflected in behavior, speaking in accordance with reality, acting in accordance with truth, and having noble character. Honesty as an intelligent character can be seen as a character possessed by an individual that is unique or special in the form of behavior or character. The characteristics are not lying, not swearing, not stealing, not lying, not breaking promises, not cheating, not cheating, not committing adultery, not extorting, not hating, not holding grudges, and not threatening others, not spreading slander, and able to admit mistakes. This honest intelligent character consists of seven aspects, namely: 1) saying what it is; 2) Doing based on truth; 3) Defend the truth; 4) Responsible; 5) Fulfill obligations and receive rights; 6) gracefully; and 7) Keeping promises (Prayitno, 2016).

Honesty speaks what it is is to show a high integrity of someone, which is a personal superiority that makes a person live healthier without burden, because they run their lives far from various pretenses and falseness (Antonius, 2006: 17). Doing on the basis of truth is a correspondence between knowledge and object, an opinion or action someone who is in accordance with (or not rejected by) others and does not harm themselves (Vardiansyah, 2008: 5). Defending the truth means releasing from danger, helping, guarding well, and maintaining the truth or honesty or the real thing. Opponents of standing up for truth are witnessing lies, telling lies, and helping people who are guilty of witnessing lies. Responsibility is a human awareness of behavior or actions that are intentional or not before God, conscience, human, and self (KBBI v1.1, 2010). Its characteristics are: have a plan ahead, persevere and keep trying, always do the best, use self-control, discipline, think before acting, consider the consequences, be responsible for every word, action, and attitude and set a good example for people others (Ikhwanudin, 2012), and staged a number of roles in social, individual or theological contexts. This is the attitude and behavior of a person to carry out their duties and obligations, which should be done, towards oneself, society, the environment (natural, social and cultural), the state and the almighty God (Ratri, 2016).

Obligation is something that is obligatory, must be carried out, duties according to law, everything that becomes a human duty, obligations based on the norms of right and wrong as accepted and recognized by society. While 'rights' can be interpreted as belonging, belonging, authority, degree, power to do something according to what has been determined by the law or rules and the right power over something to demand something (KBBI v1.1, 2010, Peter, 1991). The ultimate goal of organizing education and as a result is the formation of intelligent characters of students, one of which is an honest character that can fulfill obligations with full responsibility and receive rights. The results of education in character must be sought from the beginning of the educational effort itself and all the actual activities carried out with character. Thus the end of 
education is character needs to be completed with the beginning, the process and the end of education are all characters (Prayitno, 2016). Relief is interpreted as feeling relieved, feeling happy, not being upset (KBBI v 1,1, 2010), which implies being sincere, sincere, patient, relieved, forgiving, forgiving, forgiving, tolerance, living in harmony, harmony, and the like (Peter, 1991). An honest attitude of relief can be proven by the ability of acceptance or tolerance which is a concession, gentleness, relief and patience of individuals towards differences, both opinions, race, culture, religion and all other differences, openness, voluntary and gentle towards it all . This graceful attitude is also related to ethics, morals and morals as well as the results of thought, heart, taste and intention.

Keeping promises means trying to fulfill all that has been promised to others in the future and this is one of the characters possessed by individuals who are educated in the values of honest intelligent characters. The opposite of keeping promises is breaking promises. Keeping promises is one of the praiseworthy qualities that show the nobleness of human mind and at the same time be a decoration that can deliver it to achieve success from the efforts made. A promise is a word that states the ability to do something, a statement by two parties to agree or be willing to do something, conditions or conditions that must be fulfilled, and others (Peter, 2000). Intelligent character learning model (Prayitno, 2016) is based on the principles of affective learning related to attitudes, interests, self-concepts, and values (Ministry of National Education, 2008, Sukarti, 2011, Nurty Gofita, 2011), for shape students into human characters (Irwan, 2016, David R. Krathwohl et. A1. 1973). This learning focus on the formation of personality and the development of individual attitudes and morals of students (Kaimuddin, 2013), becoming a person who has faith and is devoted to God who is almighty, honest, smart, tough, caring, integrity, fair, and has freedom (Famahato, 2016).

Around the world, character education was first coined by the German pedagogue F.W. Foerster in 18691966 who emphasized the ethical spiritual dimension in the process of personal formation. This education emerged as a reaction to the stagnation of Rousseauian natural pedagogy and pedagogical pedagogical instrumentalism and puerocentric pedagogy through celebrations of the spontaneity of children (Edouard Claparéde, Ovide Decroly, Maria Montessori) which colored pedagogy in Europe and the United States in the early 19th century (Hadi, 2015).

In Indonesia character education has been launched since 1947, along with the start of the implementation of the curriculum system with the vision and mission of character based education that prioritizes character education, state awareness and society. The development of this educator in 1964 was called Pancawardhana which focused on five powers, namely power: creativity, taste, intention, work, and morals. Changes occurred in 1952, 1964, 1968, 1975, 1984, 1994, 2004, 2006 to 2013, and became an important priority in development (Abna, 2014). Subjects are classified into five groups of fields of study, namely: moral, intelligence, emotional / artistic, skills and physical (Kaimuddin, 2013). This education is a formation of character values for students which includes components of awareness, understanding, care and commitment to instill these values, both to the almighty God, self, others, the environment, society and the nation as a whole become perfect human beings naturally (Linckona, 2012). So students have values and character as their own character, apply it in their lives as members of society, citizens who are religious, nationalist, productive and creative (Ministry of National Education, 2010: 4) and become fully human beings who character in the dimensions of the heart, thought, body, and taste and intention (Samani, 2012).

Intelligent character education is a plus character education, involving aspects of knowledge (cognitive), feeling, and action, (Zulnuraini, 2012). The process can be seen as a conscious and deliberate effort, as a sincere effort to overcome, establish and maintain ethical values, both for oneself and for all citizens or the nation as a whole. The goals (Ministry of National Education, 2010) are: 1) developing the potential of the conscience / affective students as human beings and citizens who have cultural values and national character; 2) develop the habits and behavior of students who are praiseworthy and in line with universal values and national cultural traditions that are religious; 3) instilling the spirit of leadership and responsibility of students as the next generation of the nation; 4) develop students' abilities to become independent, creative, national-minded human beings; and 5) developing the school / campus life environment as a learning environment that is safe, honest, full of creativity and friendship as well as with a high sense of nationality and full of strength or dignity.

Some conclusions from the results of research from around the world reveal that character learning increases academic achievement, positive behavior, self-esteem, soft skills and morality as well as various other characters and achievements, as outlined here. The application of character learning to 681 elementary schools in California over a four-year period showed a positive correlation with learning outcomes that were very different before, that is, if the higher the application of character learning, the higher the student learning outcomes (Benninga, 2003). The results of a review of 261 articles (Chiara, 2016) published in 145 academic journals selected from collection sources: Education, ERIC, Psychology and Behavioral Sciences during the period 20052014, show that the main tendency of international literature is in the category of character education. In Pekuncen (Rukhul, 2014), character education is very important in shaping the affective domain of students and strengthening the character of honesty, personality, intelligence and creativity. In Memphis USA (Kinkopf, 2016) concluded that learning character development and ethics have a major impact on behavior / bring 
positive student behavior. Parkay's research results (2010) conclude that character-based learning can improve academic achievement.

Research results in Taiwan (Lee, 2014), reveal that there are positive changes in the behavior and social interactions of students when the six core personal character values are incorporated into learning, namely character: caring and ignoring others, assessing courage, cooperation, respect, responsibility and honesty. At Sophia Bulgaria (Dodds, 2015, character learning has a very large contribution to the behavior of students, which is a decrease in overall negative behavior after being given an understanding of character values. In the city center of Eskişehir Turkey (Çubukçu, 2012), the results of research conducted on 40 elementary school students in grades 6, 7 and 8 of three schools in the 2009-2010 school year, stated that the value of the values contained in the school year was very large. curriculum and curriculum support activities are hidden in the process of obtaining and internalizing values. In Nigeria (Elizabeth, 2015) concluded that building character is as important as improving the standards and quality of learning to seek academic excellence among college students.

The results of research at Muradiye Manisa (Pala, 2011), recommend that character learning be applied because it has a very large contribution to academic achievement. Then it is necessary to guide students to know, pay attention and act based on core ethical values such as respect, responsibility, honesty, justice, compassion and others to help them develop good character. In Lebanon (Najah, 2015), recommended reforming character education in public schools. In Rome, Italy (Sölay, 2013), concluded that the mission of higher education is not only science but also character education to help people guarantee a better and moral future.

The results of research in Kwait (Tannir, 2013), conclude that there is a big influence on self-esteem and soft skills, the groups learned by character learning have higher self-esteem ranks than those taught by traditional learning. In Padua Italy (Chiara, 2016, character education plays an important role in building children's balance and youth identity and can be a special intervention for youth education and their social welfare. In North Korea (Hyungsook, 2014), character learning with socially engaging art practices encourages students to promote creativity, a sense of responsibility towards citizens, critical thinking, reflection, an interest in social justice, and consideration of people who live in the community local.

Research results in Indonesia: in Bali (Wijana, 2015), revealed that the incorporation of character education into course teaching materials can improve student soft skills; in Purwokerto (Najmudin, 2011), the morale of students who take ethics classes is better than those who have not taken it; in Lampung (Brojonegoro, 2016), the application of moral reasoning learning models is more effective in improving student morality; and in Jakarta (Sardjijo, 2017), recommending that character types and characters be chosen and be integrated into the learning plan.

Related to some of the research results above, the purpose of this study is to reveal the differences in the honest attitude of students before and after being taught with intelligent character learning models in higher education. This learning model does not yet exist and its superiority from the results of other studies is specifically applying the intelligent character learning model to shape the honest character of the participants. Existing learning is only ordinary character learning and not intelligent character learning models.

\section{Method}

This study uses an experimental approach to the One-Group Pretest-Posttest Design method. As a subject, the sample (total sampling), the source of the data is the first semester students majoring in economic education at the Faculty of Social Sciences IKIP Gunungsitoli as many as 45 people, carried out in July - November 2019. The data collection instrument was a closed questionnaire that was arranged based on seven points of honest intelligent character, namely: 1) speak as is, 2) act on the basis of truth, 3) defend the truth, 4) take responsibility, 5) fulfill obligations and receive rights, 6) gracefully, and 7) keep promises. The paradigm of this study is "O1 X $\mathrm{O} 2$ " ie $\mathrm{O} 1=$ initial test (pretest), given to assess the honest character of students before being treated $(\mathrm{X})=$ taught with intelligent character learning models. $\mathrm{O} 2=$ final test (posttest) is given to assess the honest character of students after being treated. Data were analyzed by paired sample t-test statistics for paired samples, namely the difference in the average of two samples (before-after learning with intelligent character learning models) in accordance with the hypothesis that has been proposed. Descriptive analysis is also carried out, namely comparing the differences in the honest character of each student using percentage analysis with score assessment criteria 1-5. A score of 1 is given if the student's honest character is between $0-20.9 \%$ meaning very dishonest, a score of 2 if it is between 21-40.9\% means dishonest, a score of 3 if it is between $41-60.9 \%$ means it is less honest, a score of 4 if it is between $61-80.9 \%$ means honest, and a score of 5 if it is between $81-100 \%$ means very honest. 


\section{Results and Discussion}

The research findings can be seen in Table 1 which shows a significant difference in the honest character of students before and after being taught with intelligent character learning models. Table 2 shows the comparison of students' honest character for each aspect.

Table 1 Differences in Honest Characters of Students Before and After Being Learned with the Intelligent Karaker Learning Model

\section{Paired Samples Test}

\begin{tabular}{|c|c|c|c|c|c|c|c|}
\hline \multirow{3}{*}{ Perlakuan } & \multicolumn{5}{|c|}{$\underline{\text { Paired Differences }}$} & \multirow{3}{*}{$\mathrm{df}$} & \multirow{3}{*}{$\begin{array}{l}\text { Sig. } \\
\text { (2-tailed) }\end{array}$} \\
\hline & \multirow[t]{2}{*}{ Mean } & \multirow[t]{2}{*}{$\begin{array}{l}\text { Std. } \\
\text { Deviatior }\end{array}$} & \multirow[t]{2}{*}{$\begin{array}{l}\text { Std. Erro } \\
\text { nMean }\end{array}$} & $\begin{array}{l}95 \% \\
\text { rinterval } \\
\text { Difference } \\
\end{array}$ & $\begin{array}{l}\text { Confidence } \\
\text { of thet }\end{array}$ & & \\
\hline & & & & Lower & Upper & & \\
\hline \multicolumn{8}{|l|}{ Pair 1} \\
\hline \multicolumn{2}{|c|}{$\begin{array}{l}\text { Before \& After are } \\
\text { taught } \quad \text { with }-37.02222 \\
\text { intelligent character } \\
\text { learning models }\end{array}$} & 1.57377 & 0.23460 & -37.49504 & -36.54941 & -157.80744 & 0.000 \\
\hline
\end{tabular}

Table 2

Comparison of Students' Honest Characters for Every Aspect Before and After Being Learned with the Smart Character Learning Model

Ideal Score $=\mathbf{2 2 5}$

\begin{tabular}{|c|c|c|c|c|c|c|c|c|c|}
\hline & \multirow{4}{*}{$\begin{array}{l}\text { HONEST } \\
\text { ASPECTS }\end{array}$} & \multicolumn{2}{|c|}{ BEFORE } & \multirow{2}{*}{\multicolumn{2}{|c|}{ Assessment }} & \multicolumn{3}{|c|}{ AFTER } & \multirow{4}{*}{$\begin{array}{l}\text { Learning } \\
\text { Outcomes = } \\
\text { - Post test-Pre } \\
\text { test Honesty } \\
\text { charakter goes } \\
\text { up by }\end{array}$} \\
\hline & & & & & & \multirow{3}{*}{ Skor } & \multirow{3}{*}{$\%$} & Assessment & \\
\hline & & \multicolumn{2}{|c|}{ Score $\%$} & \multirow{2}{*}{$1-5$} & \multirow{2}{*}{ Criteria } & & & \multirow{2}{*}{ 1-5 Criteria } & \\
\hline & & & & & & & & & \\
\hline 1 & Speak honestly & 90 & 40 & 2 & Dishonest & 224 & 99,55 & 5 Very honest & $60,00 \%$ \\
\hline 2 & $\begin{array}{l}\text { Honesty acts on the basis of } \\
\text { truth }\end{array}$ & & 28 & 2 & Dishonest & 221 & 98,22 & 5 Very honest & $70,22 \%$ \\
\hline 3 & $\begin{array}{l}\text { Honesty in learning, doing } \\
\text { assignments, and scientific } \\
\text { work }\end{array}$ & & 39,11 & 2 & Dishonest & 214 & 95,11 & 5 Very honest & $56,00 \%$ \\
\hline 4 & Honesty in working properly & 54 & 24 & 2 & Dishonest & 219 & 97,33 & Very honest & $73,33 \%$ \\
\hline 5 & Honesty defends the truth & 90 & 40 & 2 & Dishonest & 207 & 92,00 & 5 Very honest & $52,00 \%$ \\
\hline 6 & $\begin{array}{l}\text { Honesty works with } \\
\text { responsibility }\end{array}$ & 87 & 38,67 & 2 & Dishonest & 224 & 99,55 & 5 Very honest & $60,88 \%$ \\
\hline 7 & Honesty works earnestly & 75 & 33,33 & 2 & Dishonest & 217 & 96,44 & 5 Very honest & $63,11 \%$ \\
\hline 8 & $\begin{array}{l}\text { Honesty carries out } \\
\text { obligations and accepts rights }\end{array}$ & 87 & 38,67 & 2 & Dishonest & 222 & 98,67 & 5 Very honest & $60,00 \%$ \\
\hline 9 & $\begin{array}{l}\text { Honesty accepts rights } \\
\text { according to obligations }\end{array}$ & 93 & 41,33 & & Not honest & 209 & 92,89 & 5 Very honest & $51,56 \%$ \\
\hline & $\begin{array}{l}\text { Honesty forgives / forgives } \\
\text { the guilty person }\end{array}$ & 98 & 43,55 & & Not honest & 223 & 99,11 & $\begin{array}{ll}5 & \text { Very honest }\end{array}$ & $55,56 \%$ \\
\hline & $\begin{array}{l}\text { Honesty obeys collective } \\
\text { agreement in deliberation }\end{array}$ & 45 & 20 & 1 & $\begin{array}{l}\text { Very } \\
\text { dishonest }\end{array}$ & 221 & 98,22 & 5 Very honest & $78,22 \%$ \\
\hline 12 & Honesty holds promise & 90 & 40 & 2 & Dishonest & 223 & 99,11 & 5 Very honest & $59,11 \%$ \\
\hline Tot & & 957 & 35,44 & & Dishonest & 2624 & 97,19 & 5 Very honest & $61,75 \%$ \\
\hline$\overline{\mathbf{R a t}}$ & a-rata & $\begin{array}{l}79,7 \\
5\end{array}$ & & & & $\begin{array}{l}218,6 \\
7\end{array}$ & & & \\
\hline
\end{tabular}


In Table 1 , the significance of Sig. of $0,000<0.05$ or calculated value $>t$ table. Based on the results of this difference analysis and in accordance with the hypothesis testing criteria, then the hypothesis Ho is rejected, meaning that there are significant differences in the honest character of students before and after being taught with intelligent character learning models. Test requirements have been done before and the result is normal and homogeneous data distribution so that data analysis can be continued for testing the research hypothesis using parametric statistics. In Table 2 the results of the analysis of data regarding the comparison of honest characters of students for each aspect before and after are taught with intelligent character learning models. Before being taught with intelligent character learning models, the honest character of students as a whole is not good or dishonest with an average score of 79.75 or only $35.44 \%$ of the ideal score. Whereas after being taught with a smart character learning model, the honest character of students becomes very good or very honest with an average score of 218.67 or $97.19 \%$ of the ideal score. The overall learning outcomes of intelligent characters that have been applied are honest karkater learners on average rose by $61.75 \%$.

In Table 1 , the significance of Sig. of $0,000<0.05$ or calculated value $>$ t table. Based on the results of this difference analysis and in accordance with the hypothesis testing criteria, then the hypothesis Ho is rejected, meaning that there are significant differences in the honest character of students before and after being taught with intelligent character learning models. Test requirements have been done before and the result is normal and homogeneous data distribution so that data analysis can be continued for testing the research hypothesis using parametric statistics. In Table 2 the results of the analysis of data regarding the comparison of honest characters of students for each aspect before and after are taught with intelligent character learning models. Before being taught with intelligent character learning models, the honest character of students as a whole is not good or dishonest with an average score of 79.75 or only $35.44 \%$ of the ideal score. Whereas after being taught with a smart character learning model, the honest character of students becomes very good or very honest with an average score of 218.67 or $97.19 \%$ of the ideal score. The overall learning outcomes of intelligent characters that have been applied are honest karkater learners on average rose by $61.75 \%$.

The results of the application of this learning prove that the intelligent character learning model is very good for improving the honest character of students. This success is due to this learning model based on the principle of affective learning, which focuses on forming personality and developing the attitudes and morals of individual students, becoming individuals who believe in and fear God who is almighty, honest, intelligent, tough, and caring. The goal is not only to achieve the knowledge / cognitive aspect, but the results of affection education that can show interest and attitude: curiosity, self-confidence, responsibility, discipline, commitment, thorough, honest, cooperation, listening to explanations, self-control, asking, answering, respect the opinions of others, and respond; and achieving aspects of performance / skills / psychomotor regarding the ability to convey: opinions, arguments, criticisms, ask questions, use good language, and speak fluently about honest characters, and train yourself to apply the values of intelligent characters learned.

\section{Conclusion}

Smart character learning model can improve the honest character of students from not good to very good or from dishonest to very honest. These aspects of honest character involve: speaking as is, acting on the basis of truth, learning, doing scientific work and work, working properly, defending truth, working earnestly and responsibly, carrying out obligations and accepting rights, forgiving / forgiving / forgiving the person who is guilty, obeys collective agreement on deliberation, and keeps promises. This learning model does not only reach the knowledge / cognitive aspect, but the results of affection education in students who can show interest and attitude: curiosity, self-confidence, responsibility, discipline, commitment, conscientious, honest, cooperation, listening to explanations, controlling themselves, ask questions, answer, respect the opinions of others, and respond; and achieving aspects of performance / skills / psychomotor regarding the ability to convey: opinions, arguments, criticisms, ask questions, use good language, and speak fluently about the values of honest characters learned, and train themselves to apply them. It is recommended that every educator use this intelligent character learning model for all learning activities.

\section{References}

Abna H., Zaim, M., Kasman, R \& Darmansyah. (2014). The development of character education curriculum for elementary student in west sumatera. International Journal of Education and Research Vol. 2 No. 6 June 2014. Retrieved from https:// www. ijern. com.

Atosokhi Gea, A. (2006). Relasi dengan Tuhan. Jakarta: Elex Media Komputindo.

Aynur, P. 2011. The need for character education. International Journal Of Social Sciences And Humanity Studies, Vol 3, No 2, 2011. Retrieved from https:// sobiad. org/ ejournals. 
Benninga, J S., Marvin W., Berkowitz, P. K \& Smith, K., (2003). The relationship of character education, Implementation And Academic Achievement In Elementary Schools. Journal of Research in Character Education, 1(1), 2003, pp. 19-32. Retrieved from https:// www. csufresno. edu/ kremen/ bonner center.

Brojonegoro, S., Purnomo, M. E., \& Suntoro, I.. (2016). Penerapan model moral reasoning untuk membentuk moralitas dan karakter siswa pada PKn. Jurnal Studi Sosial, Vol 4, No 1 (2016 Retrieved from https://media. neliti. com/ media/ publications.

Chiara, P. (2016). Character education: themes and researches. An academic Literature Review. Character Education C. Pattaro Italian Journal Of Sociology Of Education, 8 (1), 2016). Retrieved from https://ijse. padovauniversitypress. it/ system.

Çubukçu, Z. (2012). The effect of hidden curriculum on character education process of primary school students. Journal, Educational Sciences: Theory \& Practice. Retrieved from https:// www. kuyeb. com.

David R. Krathwohl et. Al. (1973). Taxonomy of educational objective, the classicafication of educational goal. Handbook II, Affective Domain. London: Longman Group LTD.

Depdiknas. 2008. Pengembangan perangkat penilaian kognitif. Jakarta: Depdiknas.

Dodds, D. M. (2015). The effects of character education on social emotional behavior. Journal. St. Catherine University Sophia, December 11, 2015. Retrieved from https:// sophia. stkate. edu/ cgi.

Elizabeth, O., Amos, A. A. \& Jonathan, O. A. (2015). Time management practices, character development and academic performance among university undergraduates: covenant university experience. Journal, Creative Education, 2015, 6, 79-86. Retrieved from https:// creativecommons. org.

Emosda. (2011). Penanaman nilai-nilai kejujuran dalam menyiapkan karakter bangsa. Jurnal Innovatio, Vol. X, No. 1, Januari-Juni 2011. Jambi: Universitas Jambi. Retrieved from https:// e-journal. iainjambi. ac. id/.

Famahato Lase. (2016). Konsep, komponen dan kedudukan skemata afeksi dalam pembelajaran (makalah tidak dipublikasikan). Padang: PPs UNP.

Hadi, S. (2015). Menggagas pendidikan karakter responsif gender. Jurnal Palastren, Vol. 8, No. 2, Desember 2015. Retrieved from https:// download. portalgaruda. org/ article.

Hyungsook, Kim. (2014). Socially engaged art practice and character education: understanding others through visual art. International Journal of Education Through Art, Vol.10, Number 1, 1 March 2014, pp. 55-69(15). Retrieved from https:// www. ingentaconnect. com.

Ikhwanuddin. (2012). Implementasi pendidikan karakter kerja keras dan kerjasama dalam perkuliahan. Jurnal Pendidikan Karakter, Tahun II, Nomor 2, Juni 2012. Retrieved from https:// journal. uny. ac. id.

Irwan Satria. (2016). Model pembelajaran afektif penanaman nilai-nilai cinta damai dalam pelajaran ilmu pengatahuan sosial. Disertasi S.3 (tidak dipublikasikan). Padang: Program Pascasarjana Universitas Negeri Padang.

Kaimuddin. (2013). Implementasi pendidikan karakter dalam kurikulum 2013. Jurnal Dinamika Ilmu Vol. 14. No 1, Juni 2014. Retrieved from https:// journal. iain- samarinda. ac. id/. [Diakses Tanggal 22 Juni 2017].

Kementerian Pendidikan Nasional. (2010). Pengembangan pendidikan budaya dan karakter bangsa: pedoman sekolah. Jakarta: Badan Penelitian dan Pengembangan Pusat Kurikulum.

KBBI v1.1. (2010). Kamus besar bahasa Indonesia. Jakarta: Retrieved from https:// pusat bahasa. Diknas. Go. Id/ kkbi.

KBBI. (2002). Kamus besar bahasa Indonesia, Pusat Bahasa Departemen Pendidikan Nasional. Jakarta: Balai Pustaka.

Kemenko Kesra. 2010. Kebijakan nasional pembangunan karakter bangsa. Jakarta.

Kinkopf, T. W., \& Cort, C. (2016). Character education: teachers' perceptions of its implementation in the classroom. Delta State University Journal of Education, Volume 6, Issue 1, Spring 2016. Retrieved from https:// www. deltastate. Edu.

Kirom, S. 2011. Filsafat ilmu dan arah pengembangan pancasila: relevansinya dalam mengatasi persoalan kebangsaan. Jurnal Filsafat Vol.21, Nomor 2, Agustus 2011. Retrieved from https:// jurnal.ugm.ac.id.

Lee, Angela. (2014). Implementing character education program through music and integrated activities in early childhood settings in Taiwan. International Journal of Music Education. Retrieved from https:// journals. sagepub. com/doi.

Lickona, T. (2012). Character matters, persoalan karakter (Terjemahan Juma Abdu Wamaungo \& Jean Antunes Rudolf Zien). Jakarta: Bumi Aksara.

Lickona, T. (2013). Pendidikan karakter: Panduan lengkap mendidik siswa menjadi pintar dan baik. Bandung: Nusa Media.

Maslamah. (2016). Nilai-nilai karakter dalam kurikulum humanistik. E-Jurnal IAIN Surakarta Volume. 1, No. 2, Juli - Desember 2016. Retrieved from https:// ejournal. iainsurakarta. ac.id.

Maunah, B. (2015). Implementasi pendidikan karakter dalam pembentukan kepribadian Holistik Siswa. Jurnal Pendidikan Karakter, Tahun V, Nomor 1, April 2015. Retrieved from https:// www. tappdf. com/ journaluny. 
Mujtahid. (2016). Model implementasi pendidikan karakter melalui pendekatan terintegrasi dalam perkuliahan. Jurnal Ulul Albab, Vol 17, No.2 Tahun 2016. Retrieved from https:// repository. uin- malang. ac. id.

Najah, G. A. R., Norma, G., \& Tarek, S. (2015). Perception of character education: the case of lebanese school leaders. Open Journal of Leadership, 2015, 4, 129-142. Published Online December 2015 in SciRes. Retrieved from https:// file. scirp. org.

Najmudin. (2011). Studi tentang intervensi etika dan peningkatan moral mahasiswa. Jurnal Bisnis dan Ekonomi (JBE), Maret 2011, Hal. 69-83 Vol. 18, No. 1. Retrieved from https:// media. neliti. com/ media/ publications.

Neviyarni, S. (2009). Pelayanan bimbingan dan konseling berorientasi khalifah fil ardh. Bendung: Alfabeta.

Nurty, G.S. (2011). Ekivalen: Aspek afektiftaksonomi bloom pada pembelajaran matematika. Retrieved from https:// download. portalgaruda. org/ article.

Pala, A. (2011). The need for character education. International Journal Of Social Sciences And Humanity Studies, Vol 3, No 2, 2011. Retrieved from https:// sobiad. org/ ejournals.

Parkay, F. W., Glen, H. J., \& Erci, A. J. (2010). Curriculum leardership: readings for developing quality educational programs. Boston: Pearson.

Peter Salim \& Yenny. (1991). Kamus bahasa Indonesia kontemporer. Jakarta: Modern English Press.

Prayitno \& Mungin, dkk. (2015). Pembelajaran melalui pelayanan BK di satuan pendidikan (Pengembangan manusia seutuhnya, panduan teknis-praktis-operasional untuk para pelaksana pelayanan BK di satuan pendidikan. Jakarta: Paramitra Publishing.

Prayitno, dkk. 2016. Pendidikan karakter cerdas - Pelatihan PKC-KO. Padang: Universitas Negeri Padang.

Ratri Rahayu. 2016. Peningkatan karakter tanggung jawab siswa melalui penilaian produk pada pembelajaran mind mapping. Jurnal Konseling GUSJIGANG Vol. 2 No. 1 (Januari-Juni 2016). Retrieved from https:// jurnal. umk. ac. id.

Rogers, Carl R. 1964. Toward a modern approach to values: the valuing process in the mature person.", The Journal of Abnormal and Social Psychology, 68(2):160-7. Retrieved from https:// www. centerfortheperson. org.

Rukhul, A. H., Suhartono \& Joharman. (2014). Implementasi pendidikan karakter dalam pembentukan ranah afektif kejujuran dalam kehidupan sosial siswa kelas V SDN pekuncen tahun pelajaran 2013/ 2014. Jurnal FKIP Universitas Sebelas Maret. Retrieved from https:// jurnal. fkip. uns. ac. id.

Samani, Muclas dan Hariyanto. 2012. Konsep dan model pendidikan karakter. Bandung: Remaja Rosdakarya.

Sardjijo., \& Hapzi, A. (2017). Integrating character building into mathematics and science courses in elementary school. International Journal Of Environmental \& Science Education 2017, Vol. 12, NO. 6, 1547-1552. Retrieved from https:// www. ijese. net/ makale - indir.

Sigit, MW. (2013). Pembelajaran kontruktivisme, teori dan aplikasi pembelajaran dalam pembentukan karakter. Bandung: Alfa Beta.

Sölay, N. (2013). A survey of values education and its connection with character education. Academic Journal of Interdisciplinary Studies MCSER Publishing, Rome-Italy Vol 2 No 3 November 2013. Retrieved from https:// citeseerx. ist. psu.edu.

Sukarti. (2011). Penilaian afektif dalam pembelajaran akuntansi. Jurnal Pendidikan Akuntansi Indonesia, Vol. IX. No. 1 -Tahun 2011, Hlm. 74 -82. Retrieved from https:// journal. uny. ac.id. Diakss Tanggal 26 Juni 2017.

Susilowati, E. (2012). Implementasi kurikulum pendidikan karakter. Yogyakarta: Citra Aji Parama.

Sutarjo Adisusilo. (2013). Pembelajaran nilai-nilai karakter: Kontruktivisme dan VCT sebagai Inovasi Pendekatan Pembelajaran Afektif. Jakarta: Raja Grafindo Persada.

Tannir, A., \& Anies, A.H. (2013). Effects of character education on the self-esteem of intellectually able and less able elementary students in kuwait. International Journal of Special Education Vol 28, No: 2, 2013. Retrieved from https:// www. international journal of specialed. com.

Vardiansyah Dani. (2008). Filsafat ilmu komunikasi, suatu pengantar. Jakarta: Indeks.

Wijana, N. (2015). Pengaruh pengintegrasian pendidikan karakter berorientasi kearifan lokal ke dalam materi ajar mata kuliah ilmu lingkungan untuk meningkatkan soft skill mahasiswa jurusan pendidikan biologi FMIPA UNDIKSHA. Jurnal Pendidikan Indonesia Vol. 4, No.2, Oktober 2015. Retrieved from https:// ejournal. undiksha. ac. id.

Zulnuraini. (2012). Pendidikan karakter: konsep, implementasi dan pengembangannya di Sekolah Dasar.

Jurnal DIKDAS, No.1, Vol.1, September 2012. Retrieved from https:// pgsduntad. Com. 